\title{
Challenge Accepted: Experiences of Turkish Faculty Members at the Time of Emergency Remote Teaching
}

Faik Özgür Karataş ${ }^{* 1}$, Sevil Akaygun ${ }^{2}$, Suat Çelik ${ }^{3}$, Mehmet Kokoç ${ }^{4}$ and SEvgi Nur YilmaZ ${ }^{5}$

$\approx$ The Covid-19 pandemic caught everyone unprepared. Higher education institutions were expected to be the least affected due to their long history of distance education, which has enabled the development of expertise and technical infrastructure, but were they? The present study focuses on faculty members' experiences at the time of emergency remote teaching and afterwards. The survey method was devised to conduct the study. An online questionnaire called the Emergency Remote Teaching Views Questionnaire was developed by the researchers and administered at higher education institutions throughout Turkey. With a combination of convenience and snowball sampling, 351 faculty members from 72 different public and private higher education institutions were reached. The descriptive analysis of the data revealed that almost $62 \%$ of the faculty members had never taken any form of training regarding online distance education before the Covid-19 pandemic. Although one fifth of the faculty members indicated that they had had distance education experience three times or more before the pandemic, around $62 \%$ of them encountered remote teaching for the first time. Many faculty members indicated that they spent more time on remote teaching than face-to-face teaching; they had trouble following students' development; the students were disinterested in the classes; they had technical problems, but they also received support from their institutions. Although only one fourth of the faculty members reported being unsure about the quality of their remote teaching, three fourths of them believed that it was not as fruitful as face-to-face teaching. This was especially evident in the area of assessment and evaluation. Based on these results, it can be concluded that higher education institutions were caught unprepared, but their adaptation was very quick.

Keywords: emergency remote teaching, higher education, Covid-19 experience, faculty member, distance education

$1{ }^{\star}$ Corresponding Author. Fatih Faculty of Education, Trabzon University, Turkey; fokaratas@trabzon.edu.tr.

2 Faculty of Education, Bogazici University, Turkey.

3 Kazim Karabekir Faculty of Education, Ataturk University, Turkey.

4 School of Applied Sciences, Trabzon University, Turkey.

5 Trabzon University, Turkey. 


\title{
Sprejet izziv: izkušnje turških akademikov med poučevanjem na daljavo $v$ izrednih razmerah
}

\author{
Faik Özgür Karataş, Sevil Akaygun, Suat Çelik, Mehmet Kokoç IN \\ Sevgi Nur Yilmaz
}

$\propto$ Pandemija covida-19 je vse ujela nepripravljene. Pričakovalo se je, da bodo visokošolske ustanove zaradi dolge zgodovine izobraževanja na daljavo, ki je omogočila razvoj strokovnega znanja in tehnične infrastrukture, najmanj prizadete. Pa je bilo res tako? Ta študija se osredinja na izkušnje akademikov med poučevanjem na daljavo v izrednih razmerah in po njem. Za izvedbo študije je bila zasnovana metoda anketiranja. Raziskovalci so razvili spletni vprašalnik, imenovan Vprašalnik o stališčih o poučevanju na daljavo v izrednih razmerah, ki so ga uporabljali na visokošolskih ustanovah po vsej Turčiji. S kombinacijo naključnega vzorčenja in vzorčenja s snežno kepo je bilo zajetih 351 akademikov iz 72 različnih javnih in zasebnih visokošolskih ustanov. Deskriptivna analiza podatkov je pokazala, da se skoraj $62 \%$ akademikov pred pandemijo covida-19 ni udeležilo nobenega usposabljanja o spletnem poučevanju na daljavo. Čeprav je petina akademikov navedla, da so imeli pred pandemijo trikrat ali večkrat izkušnjo z izobraževanjem na daljavo, se jih je približno $62 \%$ s poučevanjem na daljavo srečalo prvič. Številni akademiki so navedli, da so za poučevanje na daljavo porabili več časa kot za poučevanje na fakulteti, da so imeli težave s spremljanjem razvoja študentov, da so bili študentje nezainteresirani za pouk, da so imeli tehnične težave, a so dobili tudi podporo svojih ustanov. Čeprav je le četrtina akademikov navedla, da niso prepričani o kakovosti svojega poučevanja na daljavo, jih je $75 \%$ menilo, da poučevanje na daljavo ni bilo tako uspešno kot poučevanje na fakulteti. To je bilo še posebej očitno na področju ocenjevanja in evalvacije. Na podlagi teh rezultatov je mogoče sklepati, da visokošolske ustanove niso bile pripravljene, a je bilo njihovo prilagajanje zelo hitro.

Ključne besede: poučevanje na daljavo v izrednih razmerah, visokošolsko izobraževanje, izkušnja s covidom-19, akademiki, izobraževanje na daljavo 


\section{Introduction}

The year 2020 marked our lives by bringing two main challenges: coping with Covid-19 and adapting to a new lifestyle without sacrificing much from our regular lives. From the perspective of education, the year provided a different experience to millions of students and faculty members all over the world, as most of the classes were carried out online at K-16. Despite the fact that everybody had been using the internet extensively for personal reasons, this mandatory transition was unexpected and therefore challenging.

With the development of internet technologies, there has been a great deal of interest in online education since the 1990s. Accordingly, various concepts, including distance education and computer-assisted learning, have been introduced in the field to express education in the online environment. In a more general sense, even though it is rooted in distance education, online education is considered a hybrid system that combines distance and traditional education (Allen \& Seaman, 2011; Hannay \& Newvine, 2006). It is similar to traditional education in terms of teacher-facilitated courses with weekly topics and objectives, readings, assignments, discussions, projects and so on, but it is web-based and distributed from a distance by employing a combination of synchronous and asynchronous methods of delivery that are offered anywhere and anytime. Thus, by promoting decentralised and interactive learning environments, online learning differs from the classical distance education model (e.g., TV-, radio- or correspondence-based) (Garrison, 2009; Toporski \& Foley, 2004).

Online learning allows educators to adapt instructional design principles by employing a wide range of tools that enable learners to remain engaged over time and space. More specifically, online learning is usually associated with collaborative constructivist approaches by employing web 2.0 tools. These tools convey the potential to connect people and rethink passive pedagogical methods common to higher education. However, it is emphasised that online learning offers the possibility of engaging learners in discourse and collaborative learning activities rather than just bridging distances between educational institutions and learners (Garrison, 2009). Moreover, online learning resources enable learners to create an individualised learning environment in terms of their personal learning needs and preferences (Lebenicnik et al., 2015).

In describing online learning, Neubauer (2002) emphasised creating multiple modalities for instruction and virtual communities that tie members of the class together as well as the school. Other principles of designing an online distance education programme or class should include student engagement 
and interactiveness, context-based teaching, low cognitive load, appropriate scaffolding, and self-directed learning.

Starting from December 2019, the Covid-19 outbreak affected the whole world in many aspects, including education (Sahu, 2020). During this period, education was carried out through different channels, including TV broadcasting and the world wide web. In general, online learning has been most widely referred to during the Covid-19 outbreak, as education at various levels was mostly carried out online. At the same time, the new concept of emergency remote teaching (ERT) has emerged, adding to the concepts used in the literature about online education. The main difference that distinguishes ERT from online education, which has been used in educational processes for years, is that ERT is not based on a planned curriculum, whereas online education is based on a planned and programmed teaching design (Hodges et al., 2020; Kyne \& Thompson, 2020).

The experience gained during the ERT period is important for understanding the needs of educators and students, so that more effective learning environments can be formed. Specifically, regarding higher education, recently conducted studies have focused on the ERT experiences of undergraduate students (Jeffery \& Bauer, 202O; Perets et al., 2020; Petillion \& McNeil, 2020; Shim \& Lee, 2020; Wilcox \& Vignal, 2020), instructors (Holton, 2020; Johnson et al., 2020) or both (Mohmmed et al., 2020).

In these studies, findings have revealed the problems experienced during the ERT process (Holton, 2020; Sandi-Urena, 2020; Shim \& Lee, 2020), the effects of the process on students (Jeffery \& Bauer, 2020; Petillion \& McNeil, 2020), the teaching methods implemented and the tools and applications used in teaching (Gares et al., 2020; Johnson et al., 2020; Perets et al., 2020), the supports needed (Johnson et al., 2020), the factors that prevent learning in the process (Kyne \& Thompson, 2020), the difficulties in conducting laboratory courses (Gares, et al., 2020; Sikora et al., 2020), and the gains obtained in the process (Osman, 2020). In the present study, the experiences of university faculty members (FMs) at the time of ERT and afterwards in Turkey were examined to shed light on the quick response to the unexpected school shutdowns.

\section{Research on Emergency Remote Teaching}

The emergent nature of remote teaching in a pandemic was such a new situation that it required conducting research as well. There have been several studies examining FMs' experiences and teaching, students' experiences and learning, as well as the settings and infrastructure of ERT. When these studies are reviewed, it is evident that the most common difficulties encountered in the process were 
technical problems, including insufficient equipment (Holton, 2020), the low speed of internet connection (Gares, et al., 2020; Sandi-Urena, 2020; Wilcox \& Vignal, 2020), disconnections experienced by many students (Kyne \& Thompson, 2020), and especially the inability of students living in rural areas to access their course content due to their internet infrastructure (Gares et al., 2020).

Regarding the process of teaching and learning, the main problem emerged in the area of assessment and evaluation (Gares et al., 2020; Osman, 2020; Wilcox \& Vignal, 2020). Wilcox and Vignal (2020) reported that the most important factor causing stress for both FMs and students during the ERT process was exams. It has been determined that FMs and students were concerned about the reliability and safety of exams. Osman (2020) also suggested that there were significant difficulties in measuring and evaluating practical skills, technical competencies and skills such as teaching practice. In order to overcome the difficulties in measurement and evaluation, it was recommended to use more flexible measurement tools and methods instead of the traditional measurement tools that have been used to measure recall (Petillion \& McNeil, 2020).

In addition, it was determined that many distracting factors in the home environment affected students' performance in learning (Holton, 2020; Kyne \& Thompson, 2020; Mohmmed et al., 2020; Petillion \& McNeil, 2020). Students expressed the difficulties of working at home because their parents and siblings were also at home during ERT (Kyne \& Thompson, 2020). Petillion and McNeil (2020) reported that $84 \%$ of students agreed with the view that "distractions caused by their physical environment reduced their ability to participate in online classes and to show their real performances".

The results of the studies indicated that the difficulties experienced during ERT affected learning in many ways. It was observed that students' class participation was reduced (Perets et al., 2020) and communication between student-student and student-instructor, which is one of the important factors affecting learning, was not conducted properly (Holton, 2020; Kyne \& Thompson, 2020; Petillion \& McNeil, 2020; Wilcox \& Vignal, 2020). Jeffery and Bauer (2020) also claimed that the rich interactions between students that are necessary for attendance, participation and learning were lost. On the other hand, it was observed that strong communication established between students and FMs before the pandemic increased the participation of students in courses (Gares et al., 2020).

In terms of the challenges faced regarding course content, courses involving practical skills such as laboratory courses required serious adaptation. Such courses were conducted by utilising both synchronous and asynchronous environments. It was reported that although students found online synchronous 
lessons especially useful in maintaining the learning process in a planned way (Petillion \& McNeil, 2020; Wilcox \& Vignal, 2020), using synchronous and asynchronous environments together was more effective (Sandi-Urena, 2020). Nonetheless, asynchronous environments were also found to be useful, as they enabled students to learn by providing the flexibility to repeat course content whenever they wanted (Schlesselman, 2020). Among the teaching methods used during ERT, students determined that the most effective learning tool that allowed them to focus on learning was homework involving conducting research, and the most inefficient method was the direct instruction method (Perets et al., 2020).

ERT was new but informative for all of us, as it showed us that our experiences can provide insight into how to be more prepared to provide better online education (Kyne \& Thompson, 2020; Mohmmed et al., 2020; Osman, 2020). Therefore, research showed that the lessons learned in this period were very important in terms of shedding light on future periods (Holme, 2020; Osman, 2020). However, it seems that more research is needed to reveal the experiences of different stakeholders in education from different educational environments. The present study will contribute to our efforts to understand the ERT experiences of students and FMs by providing a wide range of coverage of different HEIs and various faculties, from education to medicine, and from engineering to arts.

The purpose of this study is therefore to scrutinise university FMs' experiences at the time of ERT and afterwards in Turkey. The research questions that guide this study are:

- What are the ERT experiences of FMs in Turkey?

- What are the professional development experiences of FMs during ERT?

- What are the teaching experiences of FMs during ERT?

- What are the perceptions of FMs regarding the support provided during ERT?

- What are the views of FMs regarding online distance education besides ERT?

\section{Method}

The present study was designed and conducted in accordance with the survey research design framework, in which people's attitudes, interests and thoughts about a specific subject are investigated (Cohen et al., 2017; Fraenkel \& Wallen, 2006). With advances in technology, online questionnaires are becoming 
widely employed tools for survey studies. In order to describe the experiences of FMs in Turkey, an online questionnaire was administered by utilising a wellknown online (web and mobile) survey tool in the fall term of 2020.

\section{Sample}

The sample of the study is composed of FMs who were teaching at HEIs and had to adopt emergency remote teaching in their courses in Turkey. The study was approved by the Institutional Review Board of the first author's university. The link to the online questionnaire and a brief solicitation note asking for their consent were sent to FMs via email or instant messaging applications. The authors' networks were used to create lists of academic staff for solicitation. Each faculty member in the list was also asked to share the link of the questionnaire with their colleagues, if possible. In this way, the sample was created according to the convenience and snowball sampling methods. It is known that the return rates of online surveys are low (Cohen et al., 2017). With the selected sampling methods, the aim was to increase the return rates and to obtain more realistic answers to the questionnaire. A total of 351 FMs working at 72 different HEIs from six different faculties or departments affiliated to these institutions participated in the study. As a result of convenience sampling, there was more participation in the study from the institutions to which the authors are affiliated. As shown in Figure 1, the distribution of the participating institutions is spread across the country, which might be considered as an indicator of country representation

\section{Figure 1}

Distribution of the number of FMs according to the cities in which their affiliated HEIs are located

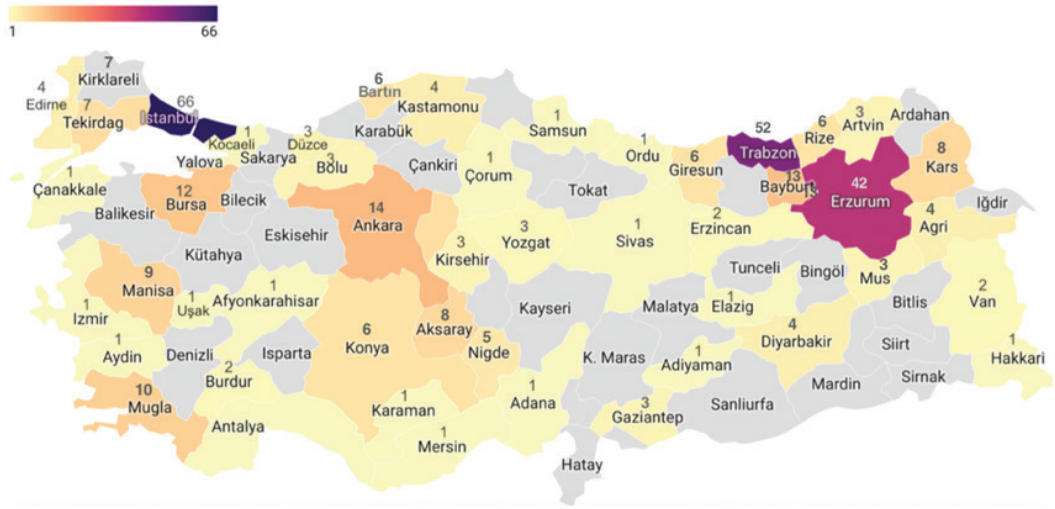


Although the participating FMs were from six different faculties, most of them were working in the faculties of education with which the authors of the present study are affiliated. As seen in Figure 2, the majority of the participants were from faculties of education.

\section{Figure 2}

Distribution of the number of FMs according to the faculties or units at which they were working
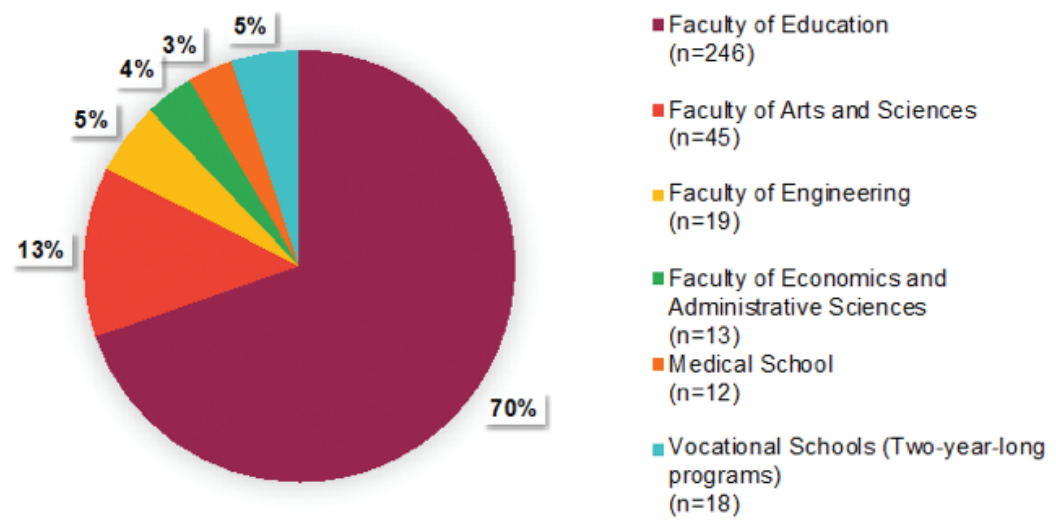

Regarding the positions of the faculty members, there is a fair distribution, as shown in Figure 3.

\section{Figure 3}

Distribution of the FMs by their positions

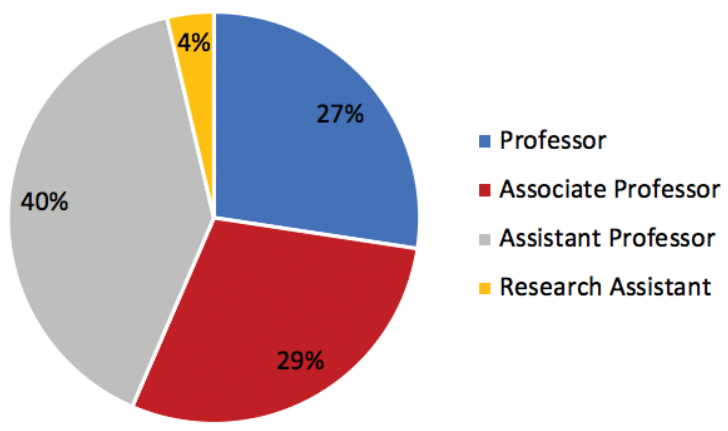




\section{Data Collection}

The data in the study were collected by a questionnaire called the Emergency Remote Teaching Views Questionnaire (ERT-VQ), which consisted of 56 items developed by the researchers. The questionnaire has five sections including both open-ended ( 14 items) and closed-ended ( 42 items) items in the form of multiple choice or Likert scale items. The first section contains 18 items to collect the FMs' demographic information and descriptive information about emergency remote teaching. The second part consists of 15 items related to the experience, perception and experiences regarding education and the information and communication technologies (ICT) used during the emergency remote teaching process. In the third part, there are 9 items to gather the respondents' views on distance education. In the fourth part, 10 items were used to collect the FMs' experiences regarding emergency remote teaching. In the fifth and last part, 4 questions were asked to determine the participants' experiences involving synchronous lecture and internet-based teaching technologies in their emergency remote teaching. After the ERT-VQ items were developed, it was piloted with 20 instructors and the detected deficiencies and inaccuracies were corrected. A Turkish linguist also reviewed and checked the items for grammatical and semantic errors.

\section{Data Analysis}

ERT-VQs with missing information were eliminated before the analysis, as were repeated submissions. The data were initially organised and elaborated using spreadsheet software. The responses were then analysed to describe the general tendency of the experiences of the FMs. Frequencies, percentages, means and standard deviation were calculated for the items based on convenience. For the qualitative data, thematic analysis was conducted.

\section{Results}

The results regarding the research problems examined within the scope of the study are presented separately.

\section{What are the professional development experiences of the FMs regarding ERT?}

Findings regarding the FMs' experiences of giving lessons through distance education before ERT are shown in Table 1, demonstrating that the majority of the FMs did not have any experience of distance education before the pandemic. 
Table 1

FMs' experiences of distance education before the Covid-19 pandemic

\begin{tabular}{llcc}
\hline & & $\mathrm{f}$ & $\%$ \\
\hline Distance learning experience before the Covid-19 pandemic & Not at all & 213 & 60.68 \\
& Once & 43 & 12.25 \\
& 2 or 3 times & 32 & 9.12 \\
& More than 3 & 63 & 17.95 \\
\hline
\end{tabular}

Findings regarding the number of online professional development activities the FMs participated in during the Covid-19 pandemic are given in Table 2.

\section{Table 2}

Number of online activities participated in during the Covid-19 pandemic

\begin{tabular}{llll}
\hline & & \multicolumn{1}{l}{ f } & \multicolumn{1}{c}{$\%$} \\
\hline $\begin{array}{l}\text { Number of professional development activities participated in } \\
\text { during the Covid-19 pandemic }\end{array}$ & Not at all & 66 & 18.80 \\
& Once & 70 & 19.94 \\
& 2 or 3 times & 113 & 32.19 \\
& 4 or 5 times & 81 & 23.08 \\
& More than 5 & 21 & 5.98 \\
\cline { 2 - 4 } & Total & 351 & 100.00 \\
\hline
\end{tabular}

It was revealed that the vast majority of the FMs (81.20\%) attended a distance education activity at least once for personal or professional development during the Covid-19 pandemic. However, 54.40\% of the FMs stated that they did not want to receive any distance education training. When the FMs who responded "Yes" to the statement "I would like to receive education" were asked what kind of education they wanted to receive, they stated that they wanted to learn other applications that could be used in distance education, and to learn applications that could be used to increase classroom interaction and to prepare and execute exams in these environments.

\section{What are the experiences of the FMs regarding ERT?}

According to the survey items with the highest score averages (see Table 3), the FMs stated that students could easily access course materials in their ERT courses during the pandemic $(M=4.18)$. However, it was revealed that they spent a lot of time on their courses during ERT $(M=4.05)$ and thought that the distance 
education given during the pandemic was not as efficient as face-to-face teaching $(M=4.01)$. It is important to note that a lack of willingness to teach through remote teaching, having technical problems during ERT courses, and the costs of the technologies used ERT were problems the FMs faced.

\section{Table 3}

Results on the teaching experiences of the FMs regarding ERT

\begin{tabular}{|c|c|c|}
\hline Items & M & SS \\
\hline During my ERT, the students could easily access the course materials. & 4.18 & .90 \\
\hline My ERT courses were not as efficient as face-to-face teaching. & 4.05 & 1.19 \\
\hline I spent a lot of time lecturing in my ERT courses. & 4.01 & 1.07 \\
\hline $\begin{array}{l}\text { I think the measurements and evaluations made in the ERT courses were not } \\
\text { reliable. }\end{array}$ & 3.97 & 1.18 \\
\hline $\begin{array}{l}\text { I am thinking of bringing my experiences in distance education during the pan- } \\
\text { demic to the face-to-face teaching process. }\end{array}$ & 3.72 & 1.11 \\
\hline $\begin{array}{l}\text { I was able to get the necessary support when I had technical problems with my } \\
\text { ERT courses. }\end{array}$ & 3.65 & 1.09 \\
\hline $\begin{array}{l}\text { During the pandemic, I had difficulty following the academic development of the } \\
\text { students. }\end{array}$ & 3.58 & 1.24 \\
\hline I observed that my students were reluctant during my ERT. & 3.45 & 1.19 \\
\hline I was able to communicate effectively with my students during the pandemic. & 3.38 & 1.00 \\
\hline I think that my ERT courses were beneficial for students. & 3.30 & 1.02 \\
\hline $\begin{array}{l}\text { During my ERT, my students communicated effectively with each other regarding } \\
\text { the course content and activities. }\end{array}$ & 3.17 & 1.11 \\
\hline The costs of the technologies used for distance education were high for lecturers. & 3.06 & 1.31 \\
\hline $\begin{array}{l}\text { In my ERT, the students could not follow the courses due to technological prob- } \\
\text { lems. }\end{array}$ & 3.08 & 1.06 \\
\hline During the pandemic, I had technical problems in my ERT. & 2.86 & 1.15 \\
\hline At the beginning of the pandemic process, I was not willing to do ERT. & 2.84 & 1.32 \\
\hline
\end{tabular}

The majority of the FMs agreed with the statement that they could generally communicate with the students during ERT via the software used. They stated that the online training provided prior to ERT was not sufficient, and that they did not have the opportunity to get to know their students sufficiently. Hence, they suggested that the ERT process could not replace face-to-face teaching. One of the FMs described the difficulties they faced during ERT as follows:

We had students with internet access problems. I had difficulty in communicating with them. We communicated via email. Participation in the online synchronous classes was unfortunately not shown. This number was very limited. In a class of 70 people, two or three people suffered from a 
similar condition. They knew how to access course materials. I tried to create a democratic classroom environment so that they could participate actively in the lessons. I made a lot of effort to give all of the students the right to speak, but it was more difficult to include some students in online education than in formal education. $(220 \mathrm{~A})$

The results shown in Table 4 indicate that the majority of the FMs did not have any experience of distance learning and teaching before the pandemic.

\section{Table 4}

FMs' teaching experiences through distance education before Covid-19

\begin{tabular}{llcc}
\hline & & f & $\%$ \\
\hline Teaching experience through distance education before Covid-19 & Not at all & 222 & 63.25 \\
& Once & 23 & 6.55 \\
& 2 or 3 times & 37 & 10.54 \\
& More than 3 & 69 & 19.66 \\
\hline
\end{tabular}

As shown in Table $5,83 \%$ of the FMs lectured in the 2020 spring term. It was noticed that the rate of FMs who prefer to teach synchronous lessons in the $2020 / 2021$ fall term was $95 \%$. The results show that the majority of the FMs said they would give lectures during the pandemic.

\section{Table 5}

Experience of synchronous teaching during the pandemic

\begin{tabular}{lccc}
\hline & & $\mathrm{f}$ & $\%$ \\
\hline Giving synchronous lessons in the 2020 spring term & Yes & 291 & 82.91 \\
& No & 60 & 17.09 \\
\hline Giving synchronous lessons in the 2020/2021 fall term & Yes & 335 & 95.44 \\
& No & 16 & 4.56 \\
\hline
\end{tabular}

Moreover, in Table 6, the reasons stated by the FMs who answered "No" to synchronous lecturing in the 2020 spring term and the 2020/2021 fall term are presented as qualitative results. As shown in Table 7, among the reasons for this, the FMs stated that asynchronous courses are preferred instead of live lessons, and that live lessons are not preferred due to lack of infrastructure. 


\section{Table 6}

Reasons for not delivering synchronous lessons in the 2020 spring term and the 2020/2021 fall term

\begin{tabular}{llc}
\hline & Qualitative codes & $\mathbf{f}$ \\
\hline $\begin{array}{l}\text { Reasons for not delivering live/synchronous lec- } \\
\text { tures in the spring term of } 2020 \text { and the fall term } \\
\text { of } 2020 / 2021\end{array}$ & Preferring only asynchronous lesson & 16 \\
& Lack of infrastructure & 7 \\
& Not preferred & 6 \\
& University regulations & 6 \\
& Personal excuses & 5 \\
& Having no class & 5 \\
& Technical incompetence & 4 \\
Insufficient level of digital competence & 3 \\
\hline
\end{tabular}

Table 7 presents the results regarding which teaching practices the FMs performed in ERT courses. As shown in the table, 40.5\% of the FMs performed all educational practices. However, it was revealed that $17.9 \%$ of the FMs performed only one type of teaching activity during ERT.

\section{Table 7}

Teaching practices performed by FMs in ERT courses.

\begin{tabular}{llcc}
\hline & & f & $\%$ \\
\hline $\begin{array}{l}\text { Teaching } \\
\text { practices } \\
\text { performed } \\
\text { during ERT } \\
\text { courses }\end{array}$ & Live sessions \& Sharing course materials & 137 & 39.00 \\
& Uploading video lectures to LMSs \& Live sessions & 51 & 14.50 \\
& Only sharing course materials & 8 & 2.30 \\
& Only uploading video lectures to LMSs & 5 & 1.40 \\
& Only uploading video lectures to LMSs \& sharing course materials & 4 & 1.10 \\
& All of the above & 142 & 40.50 \\
\hline
\end{tabular}

Table 8 presents data regarding the participation of students in synchronous lessons during the ERT process. The findings in Table 8 show that based on the observations of the FMs, the majority of students attended live courses during ERT. 


\section{Table 8}

Frequency of students' participation in synchronous classes

\begin{tabular}{llcc}
\hline Item & Code & f & $\%$ \\
\hline Students' participation in online courses & I did not teach live sessions & 6 & 1.70 \\
& Very few participated & 36 & 10.30 \\
& Less than half participated & 49 & 14.00 \\
& Half participated & 47 & 13.40 \\
& More than half participated & 163 & 46.40 \\
& Full participation & 50 & 14.20 \\
\hline
\end{tabular}

\section{How do the FMs perceive the support that was provided during ERT?}

Table 9 shows that the majority of the FMs received support to increase their knowledge and skills related to distance education, both technically and pedagogically, during the pandemic. Some of them (14\%) stated that they received pedagogical support - reporting having attended online open access courses, seminars and webinars provided by the institution - but it was revealed that this support was more limited in the pedagogical field. It was observed that the technical support received by the FMs was about hardware, infrastructure, online training, content development, and the use of technical and web 2.o tools. In addition, almost half of the FMs stated that their institutions shared resources and supported them for effective ERT courses.

\section{Table 9}

FMs' views on the support provided during ERT

\begin{tabular}{llll}
\hline Items & & $\mathbf{f}$ & $\%$ \\
\hline Receiving technical support before teaching during the pandemic & Yes & 101 & 28.80 \\
& Partially & 114 & 32.50 \\
& No & 136 & 38.70 \\
\hline Receiving pedagogical support to improve competence in distance & Yes & 48 & 13.70 \\
education before teaching during the pandemic & Partially & 64 & 18.20 \\
& No & 239 & 68.10 \\
\hline Degree of affiliated institutions support or sharing resources during & Yes & 169 & 48.10 \\
ERT & Partially & 68 & 19.40 \\
& No & 114 & 32.50 \\
\hline
\end{tabular}


Findings regarding the FMs' motivation for ERT courses and their possible anxiety are given in Table 10. Many of the FMs indicated that ERT has changed their teaching motivation mostly in a negative way: "ERT increased my workload enormously" (327A), "We also need to review students' assignments as mandatory. I'm discouraged to know that this assessment will not be validated." (328A). A few FMs indicated a positive motivational effect of ERT: "I had the opportunity to review and employ instructional technologies for learning and teaching in the Covid-19 period. I thought that my teaching motivation increased as I applied active, participation-enhancing teaching methods." (333A).

\section{Table 10}

Motivation and anxiety of the FMs regarding ERT courses

\begin{tabular}{llcc}
\hline Items & & $\mathrm{f}$ & $\%$ \\
\hline Impact of ERT on teaching motivation & Decreased & 173 & 49.30 \\
& Not changed & 145 & 41.30 \\
& Increased & 33 & 9.40 \\
\hline Concerns about teaching before starting ERT & Yes & 122 & 34.80 \\
& Partially & 166 & 47.30 \\
& No & 63 & 17.90 \\
\hline Concerns in the fall term & Yes & 42 & 16.00 \\
& Partially & 127 & 48.30 \\
& No & 94 & 35.70 \\
\hline
\end{tabular}

Even though the FMs' concerns about ERT decreased from the spring to the fall term, more than half of them still have concerns. The factors that cause concerns include not being able to communicate effectively with students, not being able to predict how the process will be carried out, and possible technical problems in live sessions. Here is a quote from one FM: "How will I explain the content? Will it be understood? How will I do the assessment? I thought about these questions a lot. On top of that, the students' inability to download course documents and technical problems were added. These things gave me the impression that ERT was inefficient." (181A).

\section{What are the views of the FMs regarding online distance education apart from ERT?}

As shown in Table 11, the FMs do not believe that assessment and evaluation can be done in distance education as in face-to-face education, nor do they think that the interaction between students, lecturers and students will be 
strong during distance education. However, it was determined that the FMs had strong beliefs that giving feedback to students in distance education is important.

\section{Table 11}

FMs' views on online distance education apart from ERT

\begin{tabular}{lcc}
\hline Items & M & SS \\
\hline It is important to give feedback to students in distance education. & 4.44 & .77 \\
Distance education is not as efficient as face-to-face teaching. & 3.95 & 1.25 \\
In distance education, students can easily access the necessary learning materials & 3.72 & 1.00 \\
for the course. & 3.27 & 1.08 \\
Students can only meet their learning needs through distance education. & 2.97 & 1.22 \\
I think I will use distance education frequently after the pandemic. & 2.67 & 1.18 \\
Interaction between students is strong during distance education. & 2.67 & 1.09 \\
In distance education, the interaction between students and FMs is strong. & 2.63 & 1.19 \\
I will strongly recommend teaching distance courses to my colleagues. & 2.47 & 1.19 \\
Assessment and evaluation can be conducted in distance education as in face-to- & & \\
face education. & &
\end{tabular}

\section{How should education be structured in HEIs after the pandemic process?}

As shown in Table 12, 81\% of the FMs reported that face-to-face teaching should be taken as a basis after the pandemic process and online distance education should be used only for supporting learners before and after face-to-face teaching. In line with this finding, $51.60 \%$ of the participants answered "no" to the question "Would you like to teach some or all of your lessons with distance education after the pandemic process?" An illustrative quote regarding the response "no" is as follows: "I think the lessons taught in the classroom are more efficient for both the student and the teacher. Students often do not attend the live class because the lectures are recorded on video anyway, so no questions are asked during the lecture. Then, most of the time, the video recordings are not watched; instead, the students demand a course grade, which reduces productivity." (186A). 
Table 12

FMs' teaching preferences in higher education after the pandemic

\begin{tabular}{llcc}
\hline Item & Code & f & $\%$ \\
\hline $\begin{array}{l}\text { Teaching structure in HEls after } \\
\text { the pandemic }\end{array}$ & $\begin{array}{l}\text { The face-to-face teaching system should be } \\
\text { essential, distance learning should only be sup- } \\
\text { portive. }\end{array}$ & 286 & 81 \\
& $\begin{array}{l}\text { They should conduct all of the theoretical lessons } \\
\text { with distance education, studies and exams } \\
\text { should be done face-to-face. }\end{array}$ & 34 & 10 \\
& $\begin{array}{l}\text { Theoretical lessons and exams should be remote, } \\
\text { and studies should be conducted face-to-face. }\end{array}$ & 10 & 3 \\
& $\begin{array}{l}\text { Theoretical lessons and some practical lessons } \\
\text { and exams should be done remotely. }\end{array}$ & 9 & 3 \\
& Other Answers & 12 & 3 \\
\hline $\begin{array}{l}\text { Teaching some or all of the } \\
\text { courses online after the pan- } \\
\text { demic }\end{array}$ & Yes & 170 & 48.4 \\
\hline
\end{tabular}

Some of the remaining $48.4 \%$ of the respondents who responded "Yes" suggested that delivering conceptual knowledge online would enable discussions in the classroom, and distance education could solve many problems. Moreover, they stated that some courses with factual knowledge could be delivered remotely, which will be more efficient for graduate students. Here is an illustrative quote: "I think that distance education is very suitable for some courses. It has good and effective teaching methods, it can better encourage the enthusiastic and responsible student in some ways." (25A).

\section{Discussion and Conclusion}

The focus of the present study is to reveal university instructors' teaching experiences at the time of ERT. Thus, teaching and professional development experiences of the instructors and their perception of the support they received and online distance education in general were examined. The experiences of the instructors were mostly negative, except for regarding students' accessibility to the course materials that they provided for the courses. This is somewhat expected, as learning management systems (LMSs) have been readily available for a long time as a platform for sharing course materials, and one would assume that many faculties would be able to utilise this opportunity. However, FMs seemed to spend more time on ERT compared to face-to-face teaching, which implies that they were novices to some extent, and were also learning and adapting to ERT (Raza et al., 2020). This finding is supported by the data 
regarding their distance education experiences before ERT (see Table 2). The FMs absolutely believed that they gained more skills about online teaching and learning, and they are willing to apply these skills to face-to-face teaching (Chiasson et al., 2015). Although it is difficult to transfer some skills in different fields, it would be easier if this were accomplished, and it seems that some FMs might update their skills to better adapt to new online education technologies (Maria Hagan \& Wassink, 2016). However, the FMs were not satisfied with the efficiency of ERT, nor with the validity of the assessment practices. This is a very common issue across the ERT literature (Gares et al., 2020; Osman, 2020; Wilcox \& Vignal, 2020). Consequently, over $80 \%$ of the FMs considered that face-to-face teaching should be primary and online education would have a subordinative role. These findings might align with assertions that the perception of online learning as being lower quality than face-to-face learning would be sealed with this massive move to online platforms (Hodges et al., 2020).

Regarding technical issues and the support system for these issues, the instructors did not report a high level of issues in technical aspects, and they gave the impression that support for such issues was at a decent level, despite the fact that almost $40 \%$ of them did not receive any technical support before ERT started. It seems that HEIs mobilised their human sources quickly to support the faculty in these emergency conditions (Sayan, 2020). However, it is obvious that no one was ready for this situation, so the competency of support staff and their working conditions are important issues, but unfortunately this cannot be addressed in the present study. Another area of support that is vital for ERT is pedagogical support, which basically deals with how to teach under these circumstances. Studies report that instructors need both pedagogical and technological support to teach online classes (Johnson et al., 2020; Osman, 2020). More than $68 \%$ of the FMs surveyed in the present study indicated that they did not receive any institutional support before the classes started. The results showed that without technical support, leaving the faculty to their own resources is like playing a blindfold game in an uncharted land. HEIs tried to deal with minimum requirements to run the programmes, but they could not devise advanced level education focusing on teaching and learning. In other words, ERT just bridged distances between educational institutions and learners, rather than engaging learners in discourse and collaborative learning activities (Garrison, 2009). On the other hand, more than half of the FMs indicated that they sought online professional development programmes or seminars to improve their teaching and participated in one or more of them after ERT started. Although many institutions offered short programmes before the fall 2020 term, especially for pedagogical aspects of ERT, they were not well-established 
programmes addressing the comprehensive needs of online education (Cevrimici Egitimler, n.d.; Durak et al., 2020; Hodges et al., 2020).

Many of the instructors had to use LMSs and other virtual classroom tools for the first time due to ERT. Thus, their expertise in using these tools was limited and still is. Although this compulsory shift might improve the skills of some, it might also have a negative impact on the perceptions of others regarding online teaching. This is why some respondents were not willing to recommend using online education and did not plan to do so, which might align with research on the self-efficacy on online teaching (Bandura, 1982). The instructors' perception of student learning, online teaching experience, future interest in teaching online, and satisfaction with teaching online are the main factors that have an impact on self-efficacy (Horvitz et al., 2015). Although the present study does not investigate the self-efficacy of the instructors, which is a limitation, the low scores of indicators from the questionnaire including a lack of the experience of mastery, the perception of student learning, and satisfaction and motivation regarding teaching online, as well as high levels of concern, suggest that the instructors' self-efficacy regarding online teaching is not high enough to strongly apply online teaching tools to their classes. On the other hand, ERT might establish a barrier for some instructors to teach online. Research about the technology acceptance model in teaching suggests that the self-efficacy of users has to be improved in order to adapt to online teaching (Fathema et al., 2015).

The present study was conducted in Turkey by collecting data from 351 FMs from 72 different HEIs out of 207. Even though FMs from a large percentage of institutions were surveyed, the majority of them were affiliated with faculties of education. Therefore, the results may not effectively represent the views of the population.

\section{Implications for Teaching and Learning}

The transformation from face-to-face education to online education was urgent and challenging due to the pandemic. Institutional and individual responses to this urgent move might not have solved all of the issues, but they enabled the education service to continue to train people at all levels, including the tertiary level. Some of the lessons learnt from the experiences of the FMs are as follows:

- It is obvious and apparent that the infrastructure should be improved for flawless online education.

- Technical support might meet the demand, but more work should be done in pedagogical aspects in the form of professional development. 
Professional development programmes should address instructional design, learning, assessment and feedback in online education, with a clear demarcation between ERT and online learning. Another important aspect that these programmes should emphasise is the fruitfulness and benefits of online education for subject-specific teaching.

- Many of the FMs had to use LMSs and other virtual classroom tools for the first time due to ERT. Thus, their expertise in using these tools is limited and self-efficacy levels are low. More research needs to be carried out to investigate the impact of compulsory ERT on teachers/FMs' self-efficacy beliefs about online teaching.

- Hybrid/blended models should be developed and delivered to address the needs of instructors to support their traditional teaching after the Covid-19 era, as many participants reported that they are willing to apply some ERT skills to support their classes. However, the FMs' self-efficacy beliefs should be improved to include the rest of FMs in order to benefit from these tools.

\section{References}

Allen, I. E., \& Seaman, J. (2011). Going the distance: Online education in the United States. Sloan Consortium.

Bandura, A. (1982). Self-efficacy mechanism in human agency. American Psychologist, 37(2), 122-147. Cohen, L., Manion, L., \& Morrison, K. (2017). Research methods in education. Routledge.

Cevrimici Egitimler. (n.d.). Teaching and learning development application and research center. https://ogem.atauni.edu.tr/cevrimici-egitimler/

Chiasson, K., Terras, K., \& Smart, K. (2015). Faculty perceptions of moving a face-to-face course to online instruction. Journal of College Teaching \& Learning (TLC), 12(3), 321-240. https://doi. org/10.1903o/tlc.v12i3.9315

Durak, G., Çankaya, S., \& İzmirli, S. (2020). Examining the Turkish universities' distance education systems during the COVID-19 pandemic. Necatibey Faculty of Education Electronic Journal of Science and Mathematics Education, 14(1), 787-809. https://doi.org/10.17522/balikesirnef.74308o Fathema, N., Shannon, D., \& Ross, M. (2015). Expanding the technology acceptance model (TAM) to examine faculty use of learning management systems (LMSs) in higher education institutions. Journal of Online Learning \& Teaching, 11(2), 210-232.

Fraenkel, J. R., \& Wallen, N. E. (2006). How to design and evaluate research in education. McGrawHill.

Gares, S. L., Kariuki, J. K., \& Rempel, B. P. (2020). Community matters: Student instructor relationships foster student motivation and engagement in an emergency remote teaching environment. Journal of Chemical Education, 97(9), 3332-3335. https://doi.org/10.1021/acs.jchemed.ocoo635 
Garrison, R. (2009). Implications of online and blended learning for the conceptual development and practice of distance education. International Journal of E-Learning \& Distance Education, 23(2), 93-104. http://www.ijede.ca/index.php/jde/article/view/471/888 Hannay, M., \& Newvine, T. (2006). Perceptions of distance learning: A comparison of online and traditional learning. Journal of Online Learning and Teaching, 2(1), 1-11.

Hodges, C., Moore, S., Lockee, B., Trust, T., \& Bond, A. (2020). The difference between emergency remote teaching and online learning. Educause Review, 27, 1-12. https://er.educause.edu/ articles/2020/3/the-difference-between-emergency-remote-teaching-and-online-learning Holme, T. A. (2020). Introduction to the Journal of Chemical Education Special Issue on insights gained while teaching chemistry in the time of COVID-19. Journal of Chemical Education, 97(9), 2375-2377. https://doi.org/10.1021/acs.jchemed.oc01087

Holton, A. J. (2020). Implementation of an emergency multisection online general chemistry curriculum in response to COVID-19 pandemic. Journal of Chemical Education, 97(9), 2878-2883. https://doi.org/10.1021/acs.jchemed.ocoo681

Jeffery, K. A., \& Bauer, C. F. (2020). Students' responses to emergency remote online teaching reveal critical factors for all teaching. Journal of Chemical Education, 97(9), 2472-2485. https://doi. org/10.1021/acs.jchemed.ocoo736 Johnson, N., Veletsianos, G., \& Seaman, J. (2020). U.S. Faculty and administrators' experiences and approaches in the early weeks of the COVID-19 pandemic. Online Learning, 24(2), 6-21. https://doi. org/10.24059/olj.v24i2.2285

Kyne, S. H., \& Thompson, C. D. (2020). The COVID cohort: Student transition to university in the face of a global pandemic. Journal of Chemical Education, 97(9), 3381-3385. https://doi.org/10.1021/ acs.jchemed.ocoo 769

Lebenicnik, M., Pitt, I., \& Istenic Starcic, A. (2015). Use of online learning resources in the development of learning environments at the intersection of formal and informal learning. The student as autonomous designer. Center for Educational Policy Studies, 5(2), 95-113.

Leidner, D. E., \& Jarvenpaa, S. L. (1995). The use of information technology to enhance management school education: A theoretical view. MIS Quarterly, 19(3)265-291.

Maria Hagan, J., \& Wassink, J. (2016). New skills, new jobs: Return migration, skill transfers, and business formation in Mexico. Social Problems, 63(4), 513-533. https://doi.org/10.1093/socpro/spwo21 Mohmmed, A. O., Khidhir, B. A., Nazeer, A., \& Vijayan, V. J. (2020). Emergency remote teaching during Coronavirus pandemic: The current trend and future directive at Middle East College Oman. Innovative Infrastructure Solutions, 5(3), 1-11. https://doi.org/10.1007/s41062-020-00326-7 Osman, M. E. (2020). Global impact of COVID-19 on education systems: The emergency remote teaching at Sultan Qaboos University. Journal of Education for Teaching, 46(4), 463-471. https://doi.or g/10.1080/02607476.2020.1802583

Perets, E. A., Chabeda, D., Gong, A. Z., Huang, X., Fung, T. S., Ng, K. Y., . . Yan, E. C. Y. (2020). Impact of the emergency transition to remote teaching on student engagement in a non-STEM undergraduate chemistry course in the time of COVID-19. Journal of Chemical Education, 97(9), 
2439-2447. https://doi.org/10.1021/acs.jchemed.ocoo879

Petillion, R. J., \& McNeil, W. S. (2020). Student experiences of emergency remote teaching: Impacts of instructor practice on student learning, engagement, and well-being. Journal of Chemical Education, 97(9), 2486-2493. https://doi.org/10.1021/acs.jchemed.ocoo733

Raza, S. A., Qazi, W., Khan, K. A., \& Salam, J. (2021). Social isolation and acceptance of the Learning Management System (LMS) in the time of COVID-19 pandemic: An expansion of the UTAUT model. Journal of Educational Computing Research, 59(2), 183-208. https://doi. org/10.1177/0735633120960421

Sahu P. (2020). Closure of universities due to coronavirus disease 2019 (COVID-19): Impact on education and mental health of students and academic staff. Cureus, 12(4), e7541. https://doi. org/10.7759/cureus.7541

Sandi-Urena, S. (2020). Experimentation skills away from the chemistry laboratory: Emergency remote teaching of multimodal laboratories. Journal of Chemical Education, 97(9), 3011-3017. https:// doi.org/10.1021/acs.jchemed.ocoo803

Sayan, H. (2020). Assessment of faculty members' views on distance education during the COVID-19 pandemic process. AJIT-e: Online Academic Journal of Information Technology, 11(42), 100-122. https://doi.org/10.5824/ajite.2020.03.004.x

Schlesselman, L. S. (2020). Perspective from a teaching and learning center during emergency remote teaching. American Journal of Pharmaceutical Education, 84(8), 1042-1044. https://doi. org/10.5688/ajpe 8142

Shim, T. E., \& Lee, S. Y. (2020). College students' experience of emergency remote teaching due to COVID-19. Children and youth services review, 119, 105578.

Sikora, A., Irby, S. M., Hall, B. L., Mills, S. A., Koeppe, J. R., Pikaart, M. J., . . Roberts, R. (2020). Responses to the COVID-19 pandemic by the Biochemistry Authentic Scientific Inquiry Lab (BASIL) CURE consortium: Reflections and a case study on the switch to remote learning. Journal of Chemical Education, 97(9), 3455-3462. https://doi.org/10.1021/acs.jchemed.ocoo729

Volery, T., \& Lord, D. (2000). Critical success factors in online education. International Journal of Educational Management, 14(5), 216-223.

Webster, J., \& Hackley, P. (1997). Teaching effectiveness in technology-mediated distance learning. Academy of Management Journal, 4o(6), 1282-1309.

Wilcox, B., \& Vignal, M. (2020). Recommendations for emergency remote teaching based on the student experience. Physics Teacher, 58(6), 374-375. https://doi.org/10.1119/10.0001828 


\section{Biographical note}

Faik Özgür Karataş, PhD, is an Associate Professor of Chemical/ Science Education at the Fatih Faculty of Education, Trabzon University. Some of his current research interests include epistemology of science and engineering, role of engineering design and formative assessment in science learning, and public understanding of science.

Sevil Akaygun, PhD, is an Associate Professor of Chemical Education at the Faculty of Education, Bogazici University. She taught high school chemistry and middle school science prior to receiving her $\mathrm{PhD}$ in chemical education from University of Northern Colorado. Her research interests include visualisations in chemistry education, nanoscience education and STEM education.

SuAt ÇELIK, PhD, is an Associate Professor of Chemical/Science Education at the Kazim Karabekir Faculty of Education, Ataturk University. He has research interest in understanding and teaching of the nature of science, teaching and teacher education, and active learning in science and chemistry education.

Менмет Кокос, $\mathrm{PhD}$, is an Associate Professor of Management Information Systems at the School of Applied Sciences,Trabzon University. He received his $\mathrm{Ph} . \mathrm{D}$. in Computer Education and Instructional Technology from Hacettepe University. His research interests primarily focus on open and distance learning, learning analytics, cognitive profiling, video use in e-learning and social media in education.

Sevgi Nur Yilmaz, is a chemistry teacher and a MS student at Trabzon University. She is interested in using Extended Reality (XR) technologies in chemistry education in and out of school settings. 